\title{
AGRO-ECOLOGICAL BASES OF PEPPERMINT CULTIVATION USING MICROBIOLOGICAL PREPARATIONS
}

\section{Vasylenko Olha ${ }^{1}$ Nikitina Olha ${ }^{2}$}

DOI: https://doi.org/10.30525/978-9934-571-89-3_95

Nowadays, great attention is paid to such agro-ecological problem as obtaining plant products with high qualitative parameters while soil fertility saving, which is especially important for the zones of Ukraine, where the anthropogenic load is close to the critical one [1, p. 11]. Preparations with effective microorganisms or microbiological preparations that may contain about 80 strains of beneficial microbes were developed to ensure mentioned processes. Yielding capacity of agricultural crops is increased, soil is cleared of chemical and biological contaminants, mechanical structure of the soil is improved, content of nutrients, first of all - humus is on the rise with the use of microbiological preparations [2, p. 2]. In addition, the technology positively affects the quality of products. And the most importantly is that the content of biologically active substances necessary for a human increases sharply [3, p. 8].

Currently, there are no scientifically-based technologies of peppermint growing with the use of microbiological preparations in any soil-and-climatic zones of Ukraine. Therefore, learning of these technological means for obtaining environmentally friendly products and recommendations for the implementation of the research results in production is very relevant.

\footnotetext{
${ }^{1}$ Uman National University of Horticulture, Ukraine

${ }^{2}$ Uman National University of Horticulture, Ukraine 
The purpose of our work was to study agro-ecological methods to grow peppermint commercial products with the use of microbiological preparations. According to the purpose, the number of tasks was set by these researches: to study peppermint plants grown with using of microbiological preparations by biometric parameters, to compare them and to evaluate the ability of these preparations to stimulate plants growth and development; to establish yielding capacity of peppermint commercial products under the use of microbiological preparations and to choose the best of them.

The research was carried out using the following microbiological preparations: EM-A - a liquid-type preparation which is ready for making of working solutions and using in production conditions; "Siaivo-2" - a new preparation of the EM "BakSib" series, concentrated form of the preparation for water dilution and introduction in the form of a solution for open and closed soil both root and out-root nutrition; EM-plate - was made of plastic with adding of "EM-ceramics" under "EM-balance" technology.

Peppermint was propagated by a vegetative method (rhizome division). Fresh unvegetated rhizomes were planted manually by checkrow pocket way $(45 \times 45 \mathrm{~cm})$ in the second decade of April. Plants were sprayed 10 days after rhizomes planting (the first year of vegetation), or after vegetation restoring next years, and then every 7 days during vegetation. EM-plates were placed in an upright position, slightly dipped into the soil at a distance of $20 \mathrm{~cm}$ from the plant.

Analysis of the received results shows that the plants of different ages differ significantly in their habit, and in the first place in height, depending on the application of microbiological preparations. Periodic treatment of the plants with solutions of such preparations as "EM-A" and "Siaivo-2" had a positive effect on the plant height in the phase of full flowering, that is, before harvesting the green mass. We got an excess of 10.7-14.0 cm (on average over the years of research) while comparing the indexes of these variants with the control.

According to the results of three-year studies, the largest number of shoots on the plants had those which were fed with solutions of "EM-A" preparation in the phase of vegetation beginning. This method of microbiological preparations application provided enlarging the shoots on the plant at 0.4-6.6 pcs in the phase of flowering beginning and at 1,6-9,2 pcs in the phase of full flowering. The smallest number of shoots on the bush -70.3 pcs was observed in the phase of full flowering on average over the years of the research in the plants of the control variant at all stages of organogenesis.

The plants which were fed with the solution of "EM-A" preparation during the entire vegetation period, which is due to more intensive branching and formation of more leaves were also distinguished by the highest area of the photosynthetic surface. In addition, the use of microbiological preparations influenced positively the development of underground, perennial part of the plant and, accordingly, it provided better conditions for plant nutrition for the next vegetation period.

In the absence of moisture in the soil and reduced air humidity, even a slight increase in leaf surface caused great loss of moisture and decrease in wateriness of 
plant tissues, which negatively affected the intensity of metabolism and in the final result could not affect negatively the productivity of plants. This is evidenced by the lower yield of $2.8 \mathrm{t} / \mathrm{ha}$ of whole plants faded to $55 \%$ in humidity in the control variants.

Implementing of the solution of EM-A preparation stimulated the growth of leaf mass and improved leaf coverage of peppermint plants during the vegetation period. Accordingly, yielding capacity of the plants in this experiment variant was the largest - 3.9 tons/ha which is more than the index in the control variant of 1.1 tons/ha $(39.3 \%)$.

Consequently, the use of microbiological preparation EM-A by its implementing during the vegetation period can be included as an effective, environmentally friendly element in the modern technology of growing this culture.

\section{References:}

1. Ivanczov D.V. (2014). Kak vosstanovyt plodorodye pochvy [How to restore soil fertility]. Organic Farming Club, vol. 1, pp. 2-3.

2. Tibursky I. Yu. (2006). Ekologichne silske gospodarstvo: kroky nazustrich. Krok pershyj: ekologichne zemlerobstvo: Posibny`k [Ecological agriculture: steps towards. Step one: ecological agriculture: A guide]. Kyiv: Publishing house of National Agrarian University. (in Ukrainian)

3. Zelinsky M. (2015). Organichne zemlerobstvo - ce shans ne vyzhyvaty, a zhyty i rozvyvatys [Organic agriculture is a chance not to survive, but to live and develop]. Agrosvit Ukrayiny, vol. 1, pp. $8-10$. 